\title{
Methanotrophic bacteria for nutrient removal from wastewater: attached film system
}

\author{
William J. Jewell, Yarrow M. Nelson, Mark S. Wilson
}

\begin{abstract}
It was hypothesized that nutrient removal from wastewater could be achieved by using methane oxidizing bacteria (methanotrophs). Because methane is inexpensive, it can be used as an energy source to encourage bacterial growth to assimilate nitrogen and phosphorus and other trace elements. This initial feasibility study used synthetic nutrient mixtures and secondary sewage effluent as feed to a laboratory-scale methanotrophic attached-film expanded bed (MAFEB) reactor operated at $35^{\circ} \mathrm{C}$ and $20^{\circ} \mathrm{C}$. The MAFEB system operated successfully at low nutrient concentrations under a variety of nutrientlimited conditions. Using a synthetic nutrient mixture with a nitrogen:phosphorus feed ratio $(w / w)$ of $9: 1$, phosphate concentrations were reduced from $1.3 \mathrm{mg} \mathrm{P} / \mathrm{L}$ to below $0.1 \mathrm{mg} \mathrm{P} / \mathrm{L}$, and ammonia was reduced from $12 \mathrm{mg} \mathrm{N} / \mathrm{L}$ to approximately $1 \mathrm{mg} \mathrm{N} / \mathrm{L}$ on a continuous flow basis, with a bed hydraulic retention time of 4.8 hours. The average nutrient uptake rates from synthetic nutrient mixtures were $100 \mathrm{mg}$ nitrogen and $10 \mathrm{mg}$ phosphorus/L of expanded bed/d. Nutrient assimilation rates increased with increasing growth rate and with increasing temperature. Nitrogen/phosphorus uptake ratios varied from 8 to 13 , and the observed yield varied from 0.11 to $0.16 \mathrm{~g}$ volatile solids (VS)/ $\mathrm{g}$ chemical oxygen demand (COD). Nutrient removal from secondary sewage effluent was successfully demonstrated using sewage effluent from two local treatment plants. Nutrient concentrations of $10-15 \mathrm{mg} \mathrm{N} / \mathrm{L}$ and $1.0-1.8 \mathrm{mg} \mathrm{P} / \mathrm{L}$ were reduced consistently below $1 \mathrm{mg} \mathrm{N} / \mathrm{L}$ and $0.1 \mathrm{mg} \mathrm{P} / \mathrm{L}$. No supplemental nutrients were added to the sewage to attain these removal efficiencies since the nutrient mass ratios were similar to that required by the methanotrophs. Removal rates were lower at $20^{\circ} \mathrm{C}$ than at $35^{\circ} \mathrm{C}$, but high removal efficiencies were maintained at both temperatures. Effluent suspended solids concentrations ranged from 8 to $30 \mathrm{mg}$ volatile suspended solids (VSS)/L, and the effluent soluble COD concentration averaged $30 \mathrm{mg} / \mathrm{L}$. Water Environ. Res., 64, 756 (1992).
\end{abstract}

KEYWORDS: attached film, expanded bed, methanotrophs, nutrient, removal, secondary effluent.

The control of nutrients in sewage is important in order to minimize oxygen utilization and eutrophication in receiving waters. Approximately $60000 \mathrm{~kg}$ of nitrogen and $12000 \mathrm{~kg}$ of phosphorus are discharged each year in the treated sewage from 10000 people (Metcalf and Eddy, Inc., 1979). Secondary sewage treatment generally does not remove these nutrients, and thus tertiary treatment systems are being mandated in many areas.

Tertiary treatments for nutrient removal include a number of physical, biological, and chemical processes. Each process usually affects only one form of one element, that is, only oxidized forms of nitrogen are removed by denitrification, ammonia can only be stripped by aeration if the $\mathrm{pH}$ is correct, and so on. A simple one-step process that could remove all forms of nitrogen and phosphorus would be an improvement. In addition, a better alternative would result in by-products with beneficial uses.

One possible approach toward achieving these goals would be the assimilation of nutrients via microbial growth. Since most aerobic bacteria have large cell yields and can use most forms of nutrients, this would appear to be an ideal nutrient removal process. However, such a system is limited by the cost of the carbon and energy source that would be required to support the large microbial yield, and by the resulting large sludge production. Depending on the carbon source used, residual substrate could also exert a negative impact on water quality. For example, the use of methanol as a growth substrate would be expensive, and residual methanol or metabolic by-products would be of significant concern with this organic energy source. Methane, on the other hand, is relatively inexpensive, and residual methane would not be expected to adversely affect water quality. Thus, methane-utilizing bacteria (methanotrophs) offer the possibility of a relatively inexpensive tertiary treatment system based on microbial nutrient assimilation.

Methanotrophs have been known to play a major role in most environments since the mid-1960s. The organisms are ubiquitous, have growth optimum in the mesophilic zone, but also grow under thermophilic conditions. They reproduce rapidly, often in less than three hours. Applications for methane-oxidizing bacteria were initially thought to be in the production of low-cost single cell protein (Vary and Johnson, 1967, and Hamer et al., 1967). Sheehan and Johnson (1971) provided characterization of microbial requirements and growth kinetics of methane-utilizing bacteria. They examined two types of methanotrophs that were nonsporulating rods. Cells in continuous culture exhibited a total nitrogen content varying from 11.7 to $12.1 \%$. Observed yields ranging from 0.13 to $0.20 \mathrm{~g}$ cells /g COD have been reported (Leak and Dalton, 1986).

There are also other benefits that could accrue from the application of methane-oxidizing bacteria in a tertiary treatment process. Aerobic polishing of wastewaters with these bacteria could oxidize many of the toxic organics, such as trichloroethene (TCE) and chloroform, that might pass through a conventional wastewater treatment facility. The capability of methanotrophs to oxidize such toxic organic compounds has been investigated extensively and holds considerable promise (Wilson and Wilson, 1985; Fogel et al., 1986; Chaudhry and Chapalamadugu, 1991; and Jewell et al., 1990). There is also a possibility that the methane monooxygenase ( $\mathrm{MMO}$ ) enzyme produced by these organisms would attack the refractory soluble organics and colorcausing compounds in wastewater. Finally, excess microbial solids may have a significant value as a high protein animal feed supplement. If a market were identified, the excess microorganisms' biomass could have a value equal to or in excess of the cost of the methane.

Hypothesized Tertiary Treatment with Methanotrophs

A comparison of a conventional tertiary treatment system to the hypothesized methanotrophic system is shown in Figure 1. 
LConventional Tertiay Wastewater Treatmens
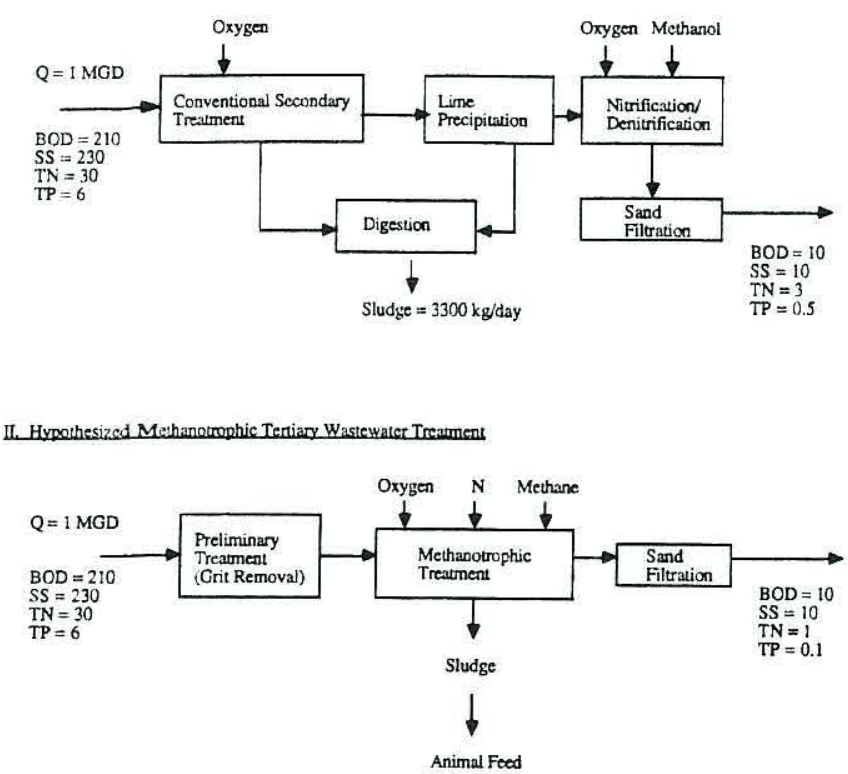

Figure 1-Overview of conventional and hypothesized methanotrophic tertiary wastewater treatment capable of reducing soluble nitrogen and phosphorus to less than 1 $\mathrm{mg} / \mathrm{L}$ each for a flow of $3800 \mathrm{~m}^{3} / \mathrm{d}(1 \mathrm{mgd})$. All values are in units of $\mathrm{mg} / \mathrm{L}$ except where noted. Conventional system based on Van Note et al. (1975).

One difference is the simplicity of the methanotrophic alternative. Methanotrophic tertiary treatment could be combined with waste stabilization (for example, activated sludge) so that only preliminary screening is needed upstream of a methanotrophic unit. This is because the oxygen demand of the sewage is minor compared to that required for methanotrophic cell synthesis of the nutrients. In order to remove both nitrogen and phosphorus, the mass ratio of these nutrients may need to be adjusted by adding nitrogen to match the ratio of nitrogen to phosphorus in the synthesized cell mass. For the example in Figure 1, the addition of approximately $120 \mathrm{~kg} /$ day of nitrogen would be required for complete phosphorus assimilation.

The large quantity of microbial sludge could be a significant disadvantage of the process. However, similar quantities of sludge could be generated by some tertiary treatment processes, such as lime precipitation. Another potential disadvantage of the process is that a substantial amount of methane would be required to generate this additional microbial mass. However, the cost of methane could potentially be offset by the value of the sludge produced if a suitable market were identified. Methanotrophs have been shown to have an ideal amino acid balance and can be used as an animal food protein source ( Vary and Johnson, 1967). Few foods have a protein content comparable to methanotrophs, which exceeds $60 \%$ of the dry weight.

Thus, it is hypothesized that the growth of methane oxidizers on domestic sewage could lead to a new process for harvesting nutrients from wastewaters. This study is intended to evaluate this concept and to define the technical feasibility of the process using laboratory-scale methanotrophic bioreactors. Several types of reactor systems can be considered for this application, including fixed-film reactors, such as trickling filters (TF), rotating biological contractors ( $R B C$ ), and attached-film expanded bed (AFEB) reactors, as well as reactors based on suspended growth. One primary concern in the design of methanotrophic bioreactors is that of supplying adequate methane to the bacteria, since methane is only sparingly soluble in water. RBC and TF systems could provide adequate gas transfer, but may involve large volumes of explosive mixtures of methane and oxygen. The methanotrophic attached-film expanded bed (MAFEB) reactor offers the possibility of separate transfer of methane and oxygen to the liquid recycle, reducing the potential for explosion. Another consideration in choosing the type of reactor is that suspended methanotrophic solids may be difficult to settle. This poor settleability may be a serious limitation of a suspended growth system, and may also limit the application of the RBC and TF systems.

In the present work, two types of reactor systems have been investigated, one using attached films in a MAFEB reactor, and the other using suspended methanotrophic growth in a completely mixed reactor. For additional details of these studies, see Jewell et al. (1989, 1990, and 1991). Experiments with the completely mixed system will be discussed in a second paper. Several MAFEB designs were investigated in this work, culminating in the design of a dual-diffuser system which was used for all experiments (Figure 2). Details of operation of this type of reactor system are described elsewhere (Fennell and Jewell, 1992).

\section{Materials and Methods}

Reactor design. The nutrient removal experiments in the fluidized bed reactor focused on two major areas. The first objective

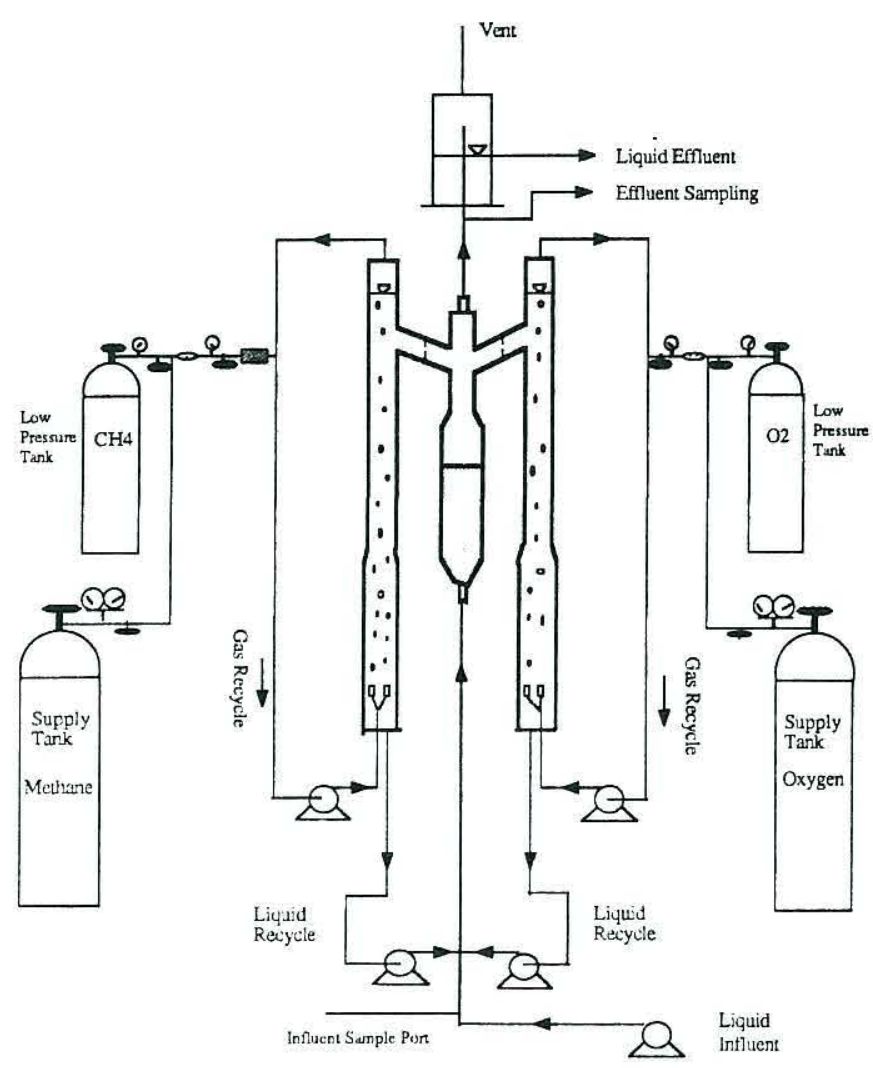

Figure 2-Schematic of MAFEB reactor used for methanotrophic nutrient removal experiments. 
was to define methanotrophic nutrient uptake kinetics and stoichiometry using synthetic nutrient mixtures, and the second objective was to evaluate the feasibility of methanotrophic tertiary treatment using experiments with actual sewage effluent. The use of synthetic nutrient mixtures allowed the investigation of nutrient assimilation under a variety of conditions, most of which were nutrient limited. A comparison was made between operation with nitrogen-limited influents, phosphorus-limited influents and influents with a balanced nitrogen phosphorus feed ratio. Treatment of sewage effluent was investigated using secondary sewage effluent from two different municipal sources.

A schematic of the dual-diffuser MAFEB reactor used for these experiments is shown in Figure 2. The fluidized bed was contained in a $5-\mathrm{cm}$ diameter glass pipe with a polytetrafluoroethylene cone at the bottom to facilitate uniform fluidization of the bed. This reactor accommodated a fluidized bed volume of up to $0.8 \mathrm{~L}$, and the total liquid volume in the system was $3.8 \mathrm{~L}$. A 10-20-cm clarifier zone was employed above the bed to settle suspended solids from the reactor effluent. Liquid recycle above the bed passed into the top of two separate bubble diffusers where counter-current exchange of oxygen and methane was accomplished by introducing the gases at the bottom of each diffuser through air stones. The diffusers were $100-\mathrm{cm}$ tall and $3.8 \mathrm{~cm}$ in diameter, expanding to $5 \mathrm{~cm}$ at the bottom to accommodate two air stones. Gases were continuously recycled through both diffusers. Make-up oxygen and methane were supplied to each diffuser from compressed gas cylinders via low-pressure regulators set at $3 \mathrm{kPa}$ ( $30 \mathrm{~cm}$ water). As the methanotrophic bacteria in the fluidized bed consumed oxygen and methane, the pressure in the respective diffuser headspaces decreased, allowing makeup gas to enter through the low-pressure regulators. Gas was fed from two 6.9-L pressurized tanks (up to $60 \mathrm{psi}$ ) which were connected to high-pressure supply tanks of oxygen or methane. Gas use was monitored daily by recording the pressure in the low-pressure gas cylinders. The entire reactor system was enclosed in a temperature-controlled chamber.

Reactor operation. Diatomaceous earth particles were used to support the attached methanotrophic films in the fluidized bed. This material was obtained from Eagle-Picher Minerals, Inc., and was sieved to provide particle sizes ranging from 300 to $1000 \mu \mathrm{m}$. Particles with mature methanotrophic films were ob- tained from a larger MAFEB reactor that was operated continuously for this purpose. This reactor was initially inoculated with settled sewage and with soil samples from a site known to contain large quantities of natural gas.

Synthetic nutrient mixtures consisted of $\mathrm{NH}_{4} \mathrm{Cl}$ (Fisher), a small amount of nitrate that was present in the tap water (1-2 $\mathrm{mg} \mathrm{N} / \mathrm{L}$ ), and equimolar mixtures of mono- and di-basic potassium phosphate (Fisher). Yeast extract (BBL Microbiology Systems) was added to the feed at a concentration of $2.5-5 \mathrm{mg}$ / $\mathrm{L}$ to provide trace nutrients. Synthetic feed mixtures were designed to provide growth conditions that were nitrogen limited, phosphorus limited, and balanced in nitrogen and phosphorus (Table 1). Alkalinity was not added to the feed, and the $\mathrm{pH}$ was allowed to drop from carbon dioxide production to between 5 and 6.

Secondary sewage effluent was obtained from two local sewage treatment plants, one in Dryden, New York and the other in Ithaca, New York. Effluent from the Dryden plant contained ammonia concentrations ranging from 10 to $30 \mathrm{mg} \mathrm{N} / \mathrm{L}$ and phosphate concentrations ranging from 1 to $3 \mathrm{mg}$ P/L. Samples from the Ithaca plant effluent had nutrient concentrations ranging from 10 to $20 \mathrm{mg} \mathrm{N} / \mathrm{L}$ and 1 to $2 \mathrm{mg} \mathrm{P} / \mathrm{L}$.

The reactor was operated with liquid recycle rates of $250 \mathrm{~mL} /$ minute from each diffuser, resulting in a nominal upflow velocity of $25 \mathrm{~cm} /$ minute. The fluidization resulting from this upflow velocity resulted in $50-100 \%$ increases in bed volume. The gas recycle rates averaged $150 \mathrm{~mL} /$ minute and $100 \mathrm{~mL} /$ minute for the oxygen and methane diffusers, respectively. Gas recycle rates were adjusted periodically to control the composition of gases in the diffuser headspaces. The methane concentration in the oxygen diffuser was maintained below $2 \%$ to avoid forming explosive mixtures of methane and oxygen. The reactor was operated at controlled temperatures ranging from 20 to $35^{\circ} \mathrm{C}$. A high growth rate was maintained by limiting the amount of initial biomass. This was accomplished by the addition of bare diatomaceous earth to the fluidized bed in addition to support media with developed attached film. Dissolved gas (methane and oxygen) concentrations were measured using a headspace analysis technique with liquid samples. Dissolved gases were measured both going into the fluidized bed and coming out above the fluidized bed to provide data pertaining to average gas concen-

Table 1-Operating conditions during MAFEB experiments with synthetic nutrient mixtures.

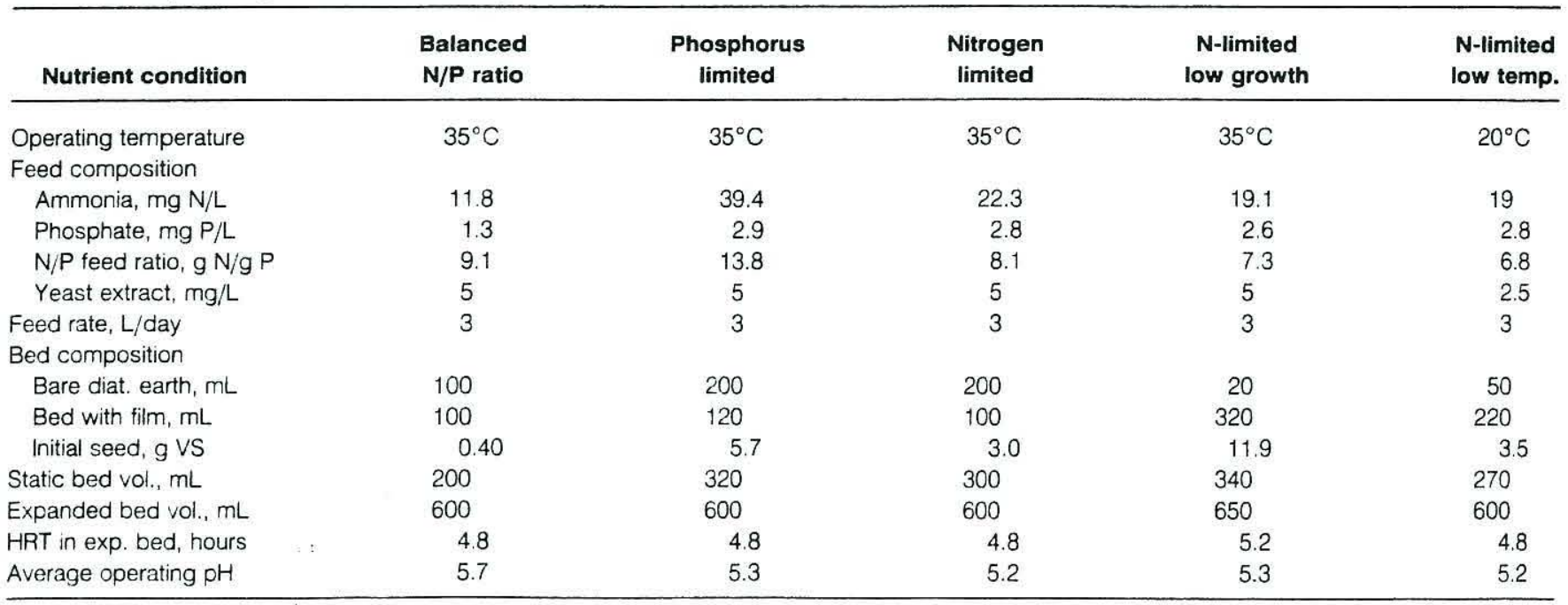


tration in the bed and gas consumption. The average dissolved methane concentration was approximately $1.2 \mathrm{mg} / \mathrm{L}$ entering the bed and approximately $0.5 \mathrm{mg} / \mathrm{L}$ exiting the bed. The average dissolved oxygen concentrations were approximately $12 \mathrm{mg} / \mathrm{L}$ at the bottom of the bed and approximately $9 \mathrm{mg} / \mathrm{L}$ above the bed.

Copper has been shown to affect the yield of methanotrophs (Leak and Dalton, 1986), and therefore copper concentrations were monitored in the reactor. Soluble copper concentrations in treated effluent were generally below $0.015 \mathrm{mg} / \mathrm{L}$. The source of copper was yeast extract in the feed during synthetic nutrient experiments.

Effluent $\mathrm{pH}$, gas compositions in the diffusers, gas use, and bed volume were monitored daily to ascertain the health of the methanotrophic culture. Daily influent and effluent samples were analyzed for ammonia, phosphate, nitrate, and nitrite, as described below. Dissolved gas concentrations and copper concentrations were determined once for each run. Attached and entrapped volatile solids in the bed were determined before and after each continuous flow run. Suspended solids were analyzed during each run, and the growth in the diffusers and on the walls of the reactor were analyzed at the end of each run. The daily growth rate was calculated from the total growth in the system, including in the bed, on the reactor walls, and suspended solids in the effluent. Likewise, the reported average biomass content of the reactor included all measured growth. Specific growth rates were calculated by dividing the daily growth rate by the total average volatile solids content in the reactor system.

Analytical procedures. Ammonia concentrations were measured using a colorimetric procedure (Rutzke, 1991). Nitrate, nitrite, and orthophosphate concentrations were measured using a Dionex Ion Chromatograph linked to a Spectra-Physics integrator, on an AS4A column with NG1-AG4A guard columns. Total suspended and volatile suspended solids of the reactor liquid were determined by methods 209C and 209D, respectively. of Standard Methods (1989). Volatile solids attached and entrapped in the bed were determined by a technique described by Clarkson (1986), in which samples of the bed were dried and weighed and then ashed at $550^{\circ} \mathrm{C}$ and weighed again. Gas concentrations of oxygen, methane, carbon dioxide, and nitrogen were determined by gas chromatography using a Gow Mac Series $580 \mathrm{GC}$ with a thermal conductivity detector.

\section{Results and Discussion}

Synthetic nutrient mixtures. The dual-diffuser MAFEB system operated successfully in continuous-flow mode under each of the experimental conditions tested. Attached films of methanotrophic bacteria developed rapidly on the diatomaceous earth support particles in the fluidized bed. For example, with phosphorus-limited growth, the attached biomass concentration in the bed increased from 18 to $32 \mathrm{~g} \mathrm{VS} / \mathrm{L}$ (based on static bed volume) in ten days of operation. Mass balances on biomass, growth rates, gas use, and yields during each of the experimental runs are summarized in Table 2 . The majority of growth occurred in the bed as attached and entrapped biomass. Lesser quantities of growth were observed in the gas transfer units and in suspension. The effluent suspended solids concentration varied from 8 to $24 \mathrm{mg} \mathrm{VSS} / \mathrm{L}$, with an average value of $14 \mathrm{mg} \mathrm{VSS} / \mathrm{L}$. Effluent quality was high, especially considering that no external settling was employed. Dissolved carbon dioxide typically de-

Table 2-Summary of reactor biomass inventory, and calculated growth rates, yields and gas use rates during synthetic nutrient experiments.

\begin{tabular}{|c|c|c|c|c|c|}
\hline Nutrient condition & $\begin{array}{l}\text { Balanced } \\
\text { N/P ratio }\end{array}$ & $\begin{array}{l}\text { Phosphorus } \\
\text { limited }\end{array}$ & $\begin{array}{l}\text { Nitrogen } \\
\text { limited }\end{array}$ & $\begin{array}{l}\mathrm{N} \text {-limited } \\
\text { low growth }\end{array}$ & $\begin{array}{l}\text { N-limited } \\
\text { low temp. }\end{array}$ \\
\hline Operating temperature & $35^{\circ} \mathrm{C}$ & $35^{\circ} \mathrm{C}$ & $35^{\circ} \mathrm{C}$ & $35^{\circ} \mathrm{C}$ & $20^{\circ} \mathrm{C}$ \\
\hline \multicolumn{6}{|l|}{ Initial biomass, g VS } \\
\hline Bed-attached & 0.4 & 5.7 & 3.0 & 10.5 & 3.5 \\
\hline Bed-entrapped & 0 & 0 & 0 & 1.4 & 0 \\
\hline Gas absorbers & 0 & 0 & 0 & 0 & 0 \\
\hline \multicolumn{6}{|l|}{ Final biomass, g VS } \\
\hline Bed-attached & 2.0 & 10.5 & 4.0 & 10.5 & 8.6 \\
\hline Bed-entrapped & 1.4 & 1.4 & 1.6 & 1.4 & 0.8 \\
\hline Gas absorbers & 1.1 & 1.8 & 1.9 & 3.6 & 0.7 \\
\hline \multicolumn{6}{|l|}{ Biomass accumulation, g VS } \\
\hline Bed-attached & 1.6 & 4.8 & 1.0 & 0 & 5.1 \\
\hline Bed-entrapped & 1.4 & 1.4 & 1.6 & 0 & 0.8 \\
\hline Gas absorbers & 1.1 & 1.8 & 1.9 & 3.6 & 0.7 \\
\hline \multicolumn{6}{|l|}{ Effluent VSS } \\
\hline Effluent conc., mg VSS/L & 24 & 15 & 13 & 8 & 11 \\
\hline Volume wasted, $\mathrm{L}$ & 18 & 33 & 27 & 54 & 30 \\
\hline Biomass wasted, g VSS & 0.4 & 0.5 & 0.3 & 0.4 & 0.3 \\
\hline \multicolumn{6}{|l|}{ Growth rates } \\
\hline Total growth, g VS & 4.5 & 8.5 & 72 & 4.0 & 6.2 \\
\hline Daily growth rate, g VS/day & 0.76 & 0.78 & 0.30 & 0.22 & 0.62 \\
\hline Specific growth rate, day ${ }^{-1}$ & 0.30 & 0.08 & 0.15 & 0.016 & 0.09 \\
\hline Average biomass, g VS & 2.5 & 9.7 & 5.3 & 13.7 & 6.7 \\
\hline $\mathrm{CH}_{4}$ use, $\mathrm{L} / \mathrm{g}$ VS.d & 0.68 & 0.24 & 0.41 & 0.13 & 0.25 \\
\hline Observed yield, g VS/g COD & 0.16 & 0.11 & 0.13 & 0.04 & 0.13 \\
\hline $\mathrm{O}_{2}$ use. L/g VS $\cdot \mathrm{d}$ & 1.32 & 0.41 & 0.73 & 0.28 & 0.37 \\
\hline $\mathrm{O}_{2}: \mathrm{CH}_{4}$ Ratıo, $\mathrm{L} / \mathrm{L}$ & 1.9 & 1.7 & 1.8 & 2.2 & 1.5 \\
\hline
\end{tabular}


Table 3-Nitrogen and phosphorous uptake rates from synthetic nutrient mixtures.

\begin{tabular}{|c|c|c|c|c|c|}
\hline Nutrient condition & $\begin{array}{l}\text { Balanced } \\
\text { N/P ratio }\end{array}$ & $\begin{array}{l}\text { Phosphorus } \\
\text { limited }\end{array}$ & $\begin{array}{c}\text { Nitrogen } \\
\text { limited }\end{array}$ & $\begin{array}{l}\mathrm{N} \text {-limited } \\
\text { low growth }\end{array}$ & $\begin{array}{l}\mathrm{N} \text {-limited } \\
\text { low temp. }\end{array}$ \\
\hline Operating temperature & $35^{\circ} \mathrm{C}$ & $35^{\circ} \mathrm{C}$ & $35^{\circ} \mathrm{C}$ & $35^{\circ} \mathrm{C}$ & $20^{\circ} \mathrm{C}$ \\
\hline \multicolumn{6}{|l|}{ Nitrogen uptake, $\mathrm{NH}_{3}+\mathrm{NO}_{3}+\mathrm{NO}_{2}$} \\
\hline Influent conc. total N, mg N/L & 11.8 & 39.4 & 22.3 & 19.1 & 18.6 \\
\hline Effluent conc. total $\mathrm{N}, \mathrm{mg} \mathrm{N} / \mathrm{L}$ & 1.2 & 11.2 & 0.32 & 3.5 & $<0.05$ \\
\hline Nitrogen removal efficiency. \% & 90 & 72 & 99 & 82 & 99.7 \\
\hline $\mathrm{N}$ uptake rate, $\mathrm{mg} \mathrm{N} / \mathrm{g} \mathrm{VS} \cdot \mathrm{d}$ & 11.8 & 8.8 & 12.6 & 3.6 & 8.2 \\
\hline $\mathrm{N}$ uptake rate, $\mathrm{mg} \mathrm{N} / \mathrm{L}_{\mathrm{eb}} \cdot \mathrm{d}$ & 53 & 142 & 110 & 78 & 93 \\
\hline Methane required, $\mathrm{g} \mathrm{CH}_{4} / \mathrm{g} \mathrm{N}$ & 37 & 20 & 23 & 29 & 22 \\
\hline \multicolumn{6}{|l|}{ Phosphorus uptake, $\mathrm{PO}_{4}$} \\
\hline Influent $\mathrm{PO}_{4}$ conc., $\mathrm{mg} \mathrm{P} / \mathrm{L}$ & 1.3 & 2.9 & 2.8 & 2.6 & 2.8 \\
\hline Effluent $\mathrm{PO}_{4}$ conc., mg P/L & $<0.1^{\mathrm{a}}$ & $<0.1^{\mathrm{a}}$ & 1.11 & 1.27 & 1.0 \\
\hline $\mathrm{PO}_{4}$ removal efficiency, \% & $100^{\mathrm{a}}$ & $100^{\mathrm{a}}$ & 60 & 52 & 64 \\
\hline $\mathrm{PO}_{4}$ uptake rate, $\mathrm{mg} \mathrm{P} / \mathrm{g} \mathrm{VS} \cdot \mathrm{d}$ & 1.4 & 0.88 & 0.95 & 0.31 & 0.80 \\
\hline $\mathrm{PO}_{4}$ uptake rate, $\mathrm{mg} P / L_{\mathrm{eb}} \cdot \mathrm{d}$ & 6.5 & 14 & 8.3 & 6.8 & 9.0 \\
\hline Methane required, $\mathrm{g} \mathrm{CH}_{4} / \mathrm{g} \mathrm{P}$ & 310 & 190 & 300 & 330 & 230 \\
\hline $\mathrm{N} / \mathrm{P}$ uptake ratio, $\mathrm{mg} \mathrm{N} / \mathrm{mg} \mathrm{P}$ & 8.2 & 10.0 & 13.3 & 11.6 & 10.3 \\
\hline $\mathrm{N} / \mathrm{P}$ ratio in feed, $\mathrm{mg} \mathrm{N} / \mathrm{mg} \mathrm{P}$ & 9.1 & 13.8 & 8.1 & 7.3 & 6.6 \\
\hline
\end{tabular}

${ }^{\mathrm{a}}$ Phosphate removed to below ion chromatograph detection limit of $0.1 \mathrm{mg} \mathrm{P} / \mathrm{L}$.

pressed the $\mathrm{pH}$ to between 5 and 6 . No adverse effects on growth kinetics were observed at these low $\mathrm{pH}$ values.

Growth rates and yields were similar for the three runs at $35^{\circ} \mathrm{C}$ under high growth rate conditions. The average daily growth rate during all three of these runs was $0.78 \pm 0.02 \mathrm{~g} \mathrm{VS} /$ day. These three runs form a controlled basis for comparison of nutrient uptake under three different types of nutrient limitation (phosphorus-limited, nitrogen-limited, and balanced N/ $P)$. The observed yields during the high growth rate experiments varied from 0.11 to $0.16 \mathrm{~g} \mathrm{VS} / \mathrm{g} \mathrm{COD} \mathrm{(Table} \mathrm{2),} \mathrm{which} \mathrm{are}$ similar to those reported in the literature for non methane-limited growth (Vary and Johnson, 1967, and Leak and Dalton, 1986).

The uptake of nitrogen and phosphorus from synthetic nutrient mixtures is summarized in Table 3. As expected, complete phosphate removal was observed under phosphorus-limited conditions, and complete ammonia removal was observed under

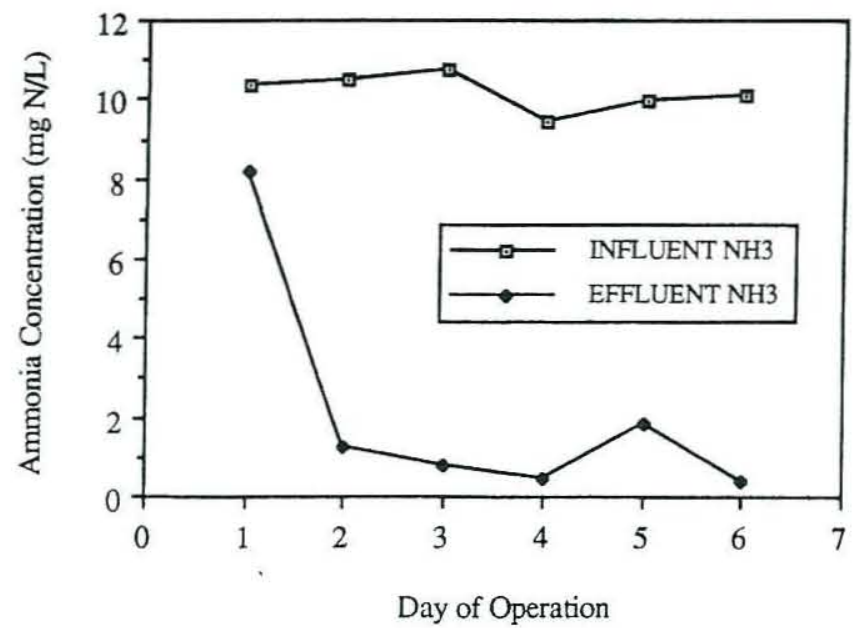

Figure 3-Ammonia removal by the MAFEB system from a synthetic nutrient mixture with a balanced $N / P$ feed ratio at $35^{\circ} \mathrm{C}$. nitrogen-limited conditions. Operation of the MAFEB system with an $\mathrm{N} / \mathrm{P}$ feed ratio of $9: 1$ at $35^{\circ} \mathrm{C}$ resulted in complete removal of phosphate and nitrate, and removed $90 \%$ of the ammonia (Table 3). During this run with a balanced N/P feed ratio, the ammonia concentration was consistently reduced from an influent concentration of about $10 \mathrm{mg} / \mathrm{L}$ to an effluent concentration of $1.2 \mathrm{mg} / \mathrm{L}$ (Figure 3 ). Phosphate was reduced from $1.3 \mathrm{mg} / \mathrm{L}$ to below $0.1 \mathrm{mg} / \mathrm{L}$, which was the detection limit of the ion chromatograph used for analysis (Figure 4). Nitrate was also reduced to undetectable levels (Figure 5).

Under phosphorus-limited growth conditions (feed N/P $=13.8)$, phosphate was continuously removed to concentrations below the detection limit $(0.1 \mathrm{mg} / \mathrm{L})$ of the ion chromatograph. The ammonia concentration was reduced from an average influent concentration of $36 \mathrm{mg} \mathrm{N} / \mathrm{L}$ to an average effluent concentration of $11 \mathrm{mg} \mathrm{N} / \mathrm{L}$, representing $70 \%$ removal of ammonia.

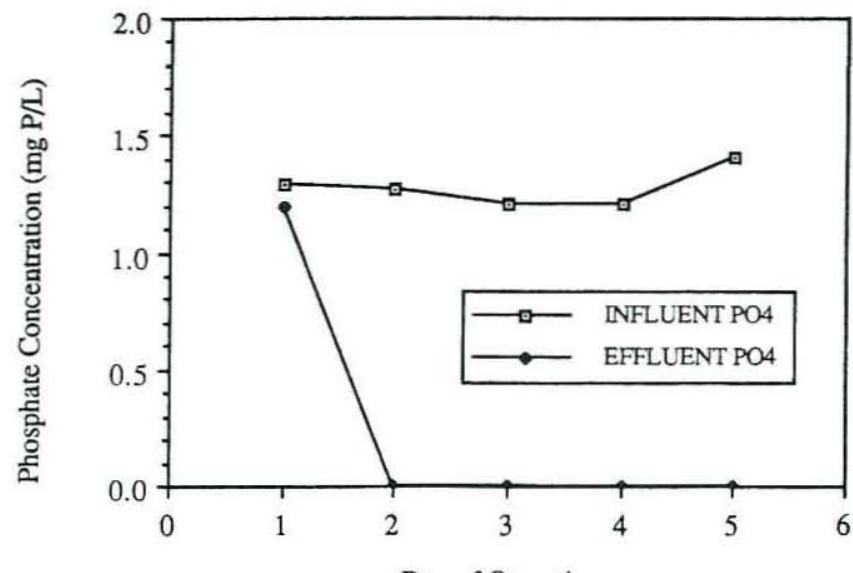

Day of Operation

Figure 4-Phosphate removal by the MAFEB system from a synthetic nutrient mixture with a balanced $N / P$ feed ratio at $35^{\circ} \mathrm{C}$. 


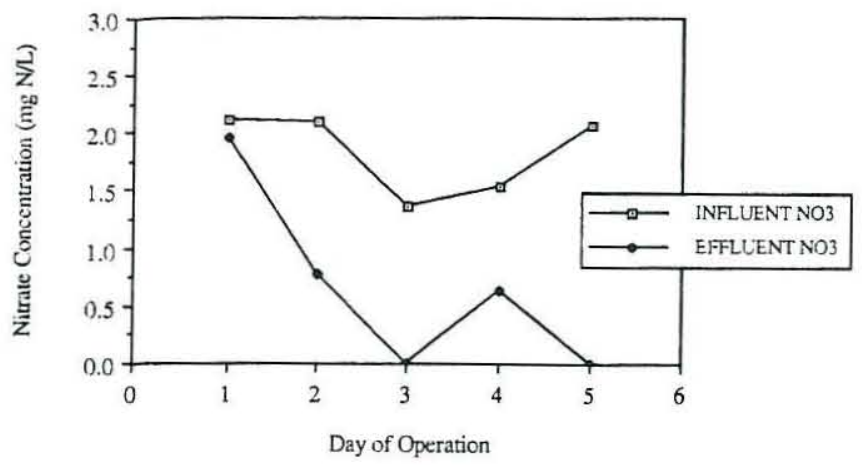

Figure 5-Nitrate removal by the MAFEB system from a synthetic nutrient mixture with a balanced $N / P$ feed ratio at $35^{\circ} \mathrm{C}$.

This low nitrogen removal efficiency was a result of the phosphorus limitation with this high $\mathrm{N} / \mathrm{P}$ feed ratio. Nitrate and nitrite concentrations in the feed averaged about $2 \mathrm{mg} \mathrm{N} / \mathrm{L}$. Both of these soluble forms of nitrogen were completely absent in the reactor effluent.

Under nitrogen-limited growth conditions ( feed N/P $=8.1$ ), complete removal of ammonia was accomplished throughout the eight day period of continuous operation, resulting in an ammonia removal efficiency of $99 \%$. As expected from the low $\mathrm{N} / \mathrm{P}$ ratio in the feed, phosphorus removal was not complete during the nitrogen-limited run. The influent phosphate concentration of $2.8 \mathrm{mg} \mathrm{P} / \mathrm{L}$ was reduced to an average of $1.1 \mathrm{mg}$ $\mathrm{P} / \mathrm{L}$ in the effluent, resulting in a phosphate removal efficiency of $60 \%$ due to limited nitrogen availability.

For the three runs with relatively high growth rates, the nutrient uptake rates on a biomass basis averaged $11 \mathrm{mg} \mathrm{N} / \mathrm{g} \mathrm{VS} \cdot \mathrm{d}$, and $1.1 \mathrm{mg} \mathrm{P} / \mathrm{g}$ VS $\cdot \mathrm{d}$ (Table 3 ). These rates were calculated based on the total average biomass content in the reactor during each run, including biomass in the gas transfer units. Expressed in terms of expanded bed volume $\left(L_{\mathrm{eb}}\right)$, the average nitrogen and phosphorus nutrient uptake rates were $100 \mathrm{mg} \mathrm{N} / L_{\mathrm{eb}} \cdot \mathrm{d}$ and $10 \mathrm{mg} \mathrm{P} / L_{\mathrm{eb}} \cdot \mathrm{d}$. Because some nutrient assimilation occurred in the gas transfer units $(21-26 \%)$, nutrient assimilation rates calculated on a per bed volume basis may be higher than would be observed without this extraneous growth. The ratio of nitrogen to phosphorus uptake ( $\mathrm{mg} \mathrm{N} / \mathrm{mg} \mathrm{P}$ ) varied from 8 to 13 , and the average value of this ratio was 10.5 . This N/P uptake ratio is somewhat higher than the ratio of 7.2 calculated from data previously reported for the composition of methanotrophic cell-mass (Sheehan and Johnson, 1971). The variation observed in the $\mathrm{N} / \mathrm{P}$ uptake ratio indicates the possibility of complete removal of both nitrogen and phosphorus nutrients from wastewaters with a range of $\mathrm{N} / \mathrm{P}$ feed ratios.

The methane requirement for nutrient assimilation varied from 20 to $37 \mathrm{~g}$ methane/g N, and from 200 to $300 \mathrm{~g}$ methane/ $\mathrm{g} \mathrm{P}$ ( Table 3 ). These variations in methane use were probably the result of variations in the nitrogen and phosphorus content of the volatile solids formed. Mass balances on nitrogen and phosphorus for the three runs with matched growth rates are shown in Table 4. Nitrogen and phosphorus contents of the biomass were not measured directly, but they were calculated from the mass balances by assuming that $100 \%$ of the consumed nutrients were incorporated into the biomass. This is a good assumption, particularly since previous work demonstrated the absence of denitrification in this system (Jewell et al., 1989). The calculated nitrogen content of the biomass correlates roughly with total nitrogen loading to the system, varying from $4 \% \mathrm{~N}$ at the lowest loading rate (balanced N/P) to $11 \%$ for the highest loading rate (P-limited). Apparently, operation of the MAFEB system under severe nutrient limited conditions resulted in the formation of nonproteinaceous storage materials. It has been reported in the literature that under conditions of excess carbon availability methanotrophs will produce storage materials composed of carbohydrates and/or fats (Harrison et al., 1972). The presence of this material was evident in these experiments as it led to dramatic changes in the physical characteristics of the fluidized bed. In these instances, particles of support media clumped together, and the fluidized bed volume increased significantly due to an apparent decrease in bed density. The formation of carbohydrate storage material is important because it could increase the amount of methane required per mass of nutrient ( $\mathrm{N}$ and $\mathrm{P}$ ) removed. Operation of the MAFEB system with the methane supply balanced with available nutrients should avoid the formation of excessive amounts of storage materials and minimize methane requirements.

The effect of growth rate on nutrient uptake was evaluated using two nitrogen-limited experimental runs with different growth rates. The low growth rate run was initiated with an initial biomass content four times higher than that of the high growth runs. This resulted in a fourfold decrease in daily growth rate and a threefold decrease in observed yield during the low growth rate experiment (Table 2). The growth rate of active biomass strongly influenced the rate of nutrient assimilation. Total nitrogen uptake decreased from $12.6 \mathrm{mg} \mathrm{N} / \mathrm{g} \mathrm{VS} \cdot \mathrm{d}$ at the

Table 4-Estimation of nitrogen and phosphorus content of biomass to achieve mass balances over a range of soluble nutrient concentrations.

\begin{tabular}{|c|c|c|c|}
\hline Nutrient condition & $\begin{array}{c}\text { Balanced } \\
\mathrm{N} / \mathrm{P}\end{array}$ & $\begin{array}{c}\text { P. } \\
\text { limited }\end{array}$ & $\underset{\text { limited }}{\mathrm{N}-}$ \\
\hline \multicolumn{4}{|l|}{ Influent nitrogen } \\
\hline Concentration, mg N/L & 11.8 & 39.4 & 22.3 \\
\hline Flow volume, $\mathrm{L}$ & 18 & 33 & 27 \\
\hline Total nitrogen loaded, g N & 0.21 & 1.3 & 0.60 \\
\hline \multicolumn{4}{|l|}{ Effluent nitrogen } \\
\hline Concentration, mg N/L & 1.2 & 11.2 & 0.32 \\
\hline Flow volume, $\mathrm{L}$ & 18 & 33 & 27 \\
\hline Total nitrogen discharged, g N & 0.022 & 0.37 & 0.008 \\
\hline \multicolumn{4}{|l|}{ Accumulated nitrogen in biomass } \\
\hline Total biomass growth, $g$ V/S & 4.5 & 8.5 & 7.2 \\
\hline Estimated nitrogen content, \% VS" & $4.2 \%$ & $11 \%$ & $8.2 \%$ \\
\hline Total nitrogen accumulation, g N & 0.19 & 0.93 & 0.59 \\
\hline \multicolumn{4}{|l|}{ Influent phosphorus } \\
\hline Concentration, mg $P / L$ & 1.3 & 2.9 & 2.8 \\
\hline Flow volume. $L$ & 18 & 33 & 27 \\
\hline Total phosphorus loaded, g P & 0.023 & 0.096 & 0.076 \\
\hline \multicolumn{4}{|l|}{ Effluent phosphorus } \\
\hline Concentration, mg P/L & $<0.1$ & $<0.1$ & 1.11 \\
\hline Flow volume, $L$ & 18 & 33 & 27 \\
\hline Total phosphorus discharged, g P & 0 & 0 & 0.030 \\
\hline \multicolumn{4}{|l|}{ Accumulated phosphorus in biomass } \\
\hline Total bicmass growth, g VS & 4.5 & 8.5 & 7.2 \\
\hline Estimated phosphorus content, \% VS & $0.5 \%$ & $1.1 \%$ & $0.6 \%$ \\
\hline Total phosphorus accumulation. gP & 0.023 & 0.096 & 0.046 \\
\hline
\end{tabular}

a Assuming all $\mathrm{N}$ and $\mathrm{P}$ consumed is incorporated into biomass formed. 
high growth rate to $3.6 \mathrm{mg} \mathrm{N} / \mathrm{g} \mathrm{VS} \cdot \mathrm{d}$ at the low growth rate (Table 3 ). The nitrogen uptake rate on a bed volume basis was also reduced at the low growth rate (Table 3 ). Since the runs with high and low growth rates were operated with a similar hydraulic retention time (HRT), the ammonia removal efficiency decreased from $99 \%$ at the high growth rate, to $80 \%$ at the low growth rate. The implication of these effects is that the solids retention time in the MAFEB system should be controlled in order to maximize nutrient removal rates and efficiencies.

Practical operation of the MAFEB system for tertiary wastewater treatment would require operation at temperatures well below $35^{\circ} \mathrm{C}$. In order to evaluate the effect of temperature on MAFEB operation, the nitrogen-limited run with synthetic nutrients was repeated at $20^{\circ} \mathrm{C}$, keeping all other operating parameters matched as closely as possible (Tables 1 and 2). At $20^{\circ} \mathrm{C}$, the MAFEB system continued to operate well, with an average $\mathrm{pH}$ of 5.2 and an effluent suspended solids concentration of 11 $\mathrm{mg} \mathrm{VSS} / \mathrm{L}$. The decrease in temperature from 35 to $20^{\circ} \mathrm{C}$ resulted in approximately a $40 \%$ reduction in specific growth rate and specific methane utilization rate (Table 2 ). The observed yield was similar at both temperatures. The nutrient uptake rates on a biomass basis $\left(\mathrm{mg} / \mathrm{g} \mathrm{VS} \cdot \mathrm{d}\right.$ ) were $15-35 \%$ lower at $20^{\circ} \mathrm{C}$ than at $35^{\circ} \mathrm{C}$, while nutrient uptake rates on a bed volume basis $(\mathrm{mg} /$ $L_{\mathrm{eb}} \cdot \mathrm{d}$ ) were similar at both temperatures (Table 3). Despite the change in growth rate, nutrient removal efficiencies were unaffected by temperature. This is probably because growth in

Table 5-MAFEB treatment of secondary sewage effluent: operating conditions, growth characteristics, and nutrient uptake.

\begin{tabular}{|c|c|c|c|}
\hline Operating temperature & $35^{\circ} \mathrm{C}$ & $22^{\circ} \mathrm{C}$ & $20^{\circ} \mathrm{C}$ \\
\hline \multicolumn{4}{|l|}{ Conditions } \\
\hline Sewage effluent source & Dryden & Dryden & Ithaca \\
\hline Feed rate, L/day & 3.0 & 3.0 & 1.9 \\
\hline Expanded bed volume, $L$ & 0.32 & 0.50 & 0.60 \\
\hline HRT in exp. bed, hours & 2.6 & 4.0 & 7.6 \\
\hline Avg. biomass in system, g VS & 2.7 & 4.5 & 4.0 \\
\hline Avg. effluent $\mathrm{pH}$ & 5.9 & 5.9 & 5.8 \\
\hline \multicolumn{4}{|l|}{ Growth characteristics } \\
\hline Specific growth rate, day ${ }^{-1}$ & 0.26 & 0.17 & 0.17 \\
\hline Methane use rate, $\mathrm{L} / \mathrm{g} \mathrm{VS} \cdot \mathrm{d}$ & 0.70 & 0.37 & 0.40 \\
\hline Observed yieid, g VS/g COD & 0.13 & 0.16 & 0.15 \\
\hline Gas use ratio, $\mathrm{L} \mathrm{O}_{2} / \mathrm{L} \mathrm{CH}_{4}$ & 1.7 & 1.5 & 1.6 \\
\hline \multicolumn{4}{|l|}{ Nutrient assimilation } \\
\hline \multicolumn{4}{|l|}{ Ammonia: } \\
\hline Influent ammonia conc., mg N/L & 14.7 & 10.0 & 14 \\
\hline Effluent ammonia conc., mg $\mathrm{N} / \mathrm{L}$ & 0.9 & 0.4 & 0.17 \\
\hline N removal efficiency, \% & 94 & 96 & 99 \\
\hline $\mathrm{N}$ uptake rate, $\mathrm{mg} \mathrm{N} / \mathrm{g} \mathrm{VS} \cdot \mathrm{d}$ & 15.3 & 6.5 & 6.7 \\
\hline $\mathrm{N}$ uptake rate, $\mathrm{mg} \mathrm{N} / L_{\mathrm{eb}} \cdot \mathrm{d}$ & 165 & 60 & 45 \\
\hline $\mathrm{CH}_{4}$ required, $\mathrm{mg} \mathrm{N} / \mathrm{g} \mathrm{COD}$ & 7.6 & 6.1 & 5.9 \\
\hline \multicolumn{4}{|l|}{ Phosphate: } \\
\hline Influent phosphate conc., mg $P / L$ & 1.8 & 1.5 & 1.0 \\
\hline Effluent phosphate conc., mg P/L & $0.0^{\mathrm{a}}$ & $0.0^{\mathrm{a}}$ & $0.0^{\mathrm{a}}$ \\
\hline P removal efficiency, \% & $34+{ }^{a}$ & $93+{ }^{a}$ & $90+{ }^{a}$ \\
\hline$P$ uptake rate, $\mathrm{mg} P / g \mathrm{VS} \cdot \mathrm{d}$ & 2.0 & 0.98 & 0.5 \\
\hline P uptake rate, mg $P / L_{e b} \cdot d$ & 22 & 9.0 & 3.2 \\
\hline $\mathrm{CH}_{4}$ required, mg $\mathrm{P} / \mathrm{g} \mathrm{COD}$. & 1.0 & 0.92 & 0.44 \\
\hline N/P uptake ratio, g N/g P & 7.6 & 6.6 & 14 \\
\hline
\end{tabular}

${ }^{a} \mathrm{PO}_{4}$ not detected in effluent with ion chromatography.

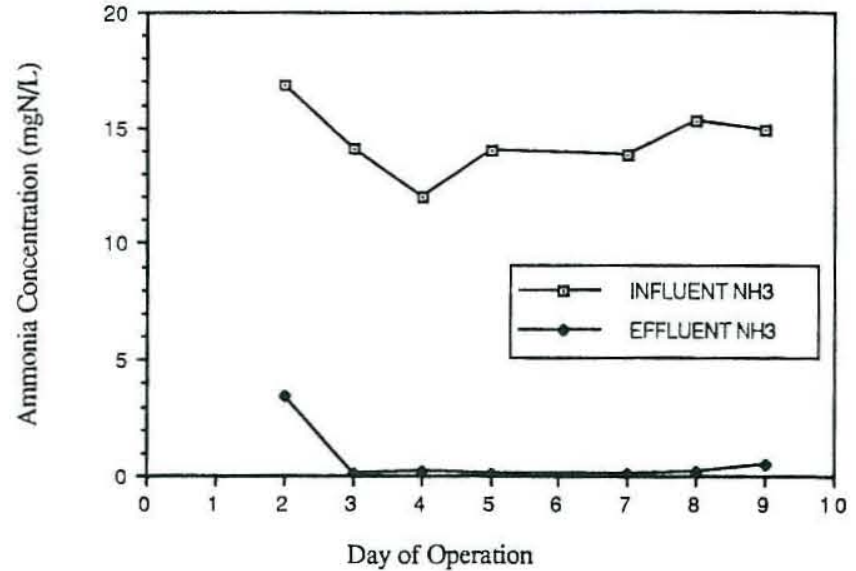

Figure 6-Ammonia removal from sewage effluent using the MAFEB reactor at $20^{\circ} \mathrm{C}$.

both runs was nutrient limited. Ammonia nitrogen was completely removed during runs at both temperatures. During operation at $20^{\circ} \mathrm{C}$, the ammonia removal efficiency was as high as $99.7 \%$, with a final effluent ammonia concentration of less than $0.05 \mathrm{mg} \mathrm{N} / \mathrm{L}$. The methane consumption rates were similar at both temperatures (Table 3 ).

Secondary sewage effluent treatment. Having demonstrated the ability of the methanotrophic system to efficiently remove nutrients from a synthetic nutrient mixture, the next step was to apply the system to treatment of actual sewage effluent from existing sewage treatment facilities. Three experimental runs were conducted using secondary sewage effluent from two local sewage treatment plants to demonstrate the feasibility of MAFEB treatment of these effluents (Table 5).

Operation of the MAFEB system with sewage effluent was similar to operation with synthetic nutrient feed, except that the operating $\mathrm{pH}$ was higher while treating sewage effluent $(\mathrm{pH}$ $=5.9$ ). The sewage effluent contained more alkalinity than the synthetic nutrient mixtures, which prevented the $\mathrm{pH}$ from being depressed as much by carbon dioxide production. Growth rates, observed yields, and gas use rates during treatment of sewage effluent were similar to those during treatment of synthetic nutrient mixtures (Tables 2 and 5 ).

Nutrient uptake during MAFEB treatment of sewage effluent is summarized in Table 5. During all of the experimental runs with sewage effluent, the ortho-phosphate concentration was reduced to below detectable levels $(0.1 \mathrm{mg} \mathrm{P} / \mathrm{L})$, and ammonia was removed with $94-99 \%$ efficiency. As an example of continuous flow sewage effluent treatment with the MAFEB system, influent and effluent concentrations of ammonia and phosphate are shown for treatment of effluent from the Ithaca plant at $20^{\circ} \mathrm{C}$ in Figures 6 and 7. Simultaneous removal of both nitrogen and phosphorus nutrients was achieved without addition of supplemental nutrients, even though the ratio of $\mathrm{N} / \mathrm{P}$ in the feeds varied from 7 to 14 (Table 5). These results confirm that the two sources of sewage effluent contained all nutrients required for methanotrophic growth, and that no additional growth factors were required for tertiary treatment with the MAFEB system.

During treatment of sewage effluent at $35^{\circ} \mathrm{C}$, the ammonia uptake rate averaged $15 \mathrm{mg} \mathrm{N} / \mathrm{g} \mathrm{VS} \cdot \mathrm{d}$, or $165 \mathrm{mg} \mathrm{N} / L_{\mathrm{eb}} \cdot \mathrm{d}$. The phosphate uptake rate averaged $2.0 \mathrm{mg} \mathrm{P} / \mathrm{g}$ VS $\cdot \mathrm{d}$, or 22 $\mathrm{mg} \mathrm{P} / L_{\mathrm{cb}} \cdot \mathrm{d}$. These uptake rates are somewhat higher than those 


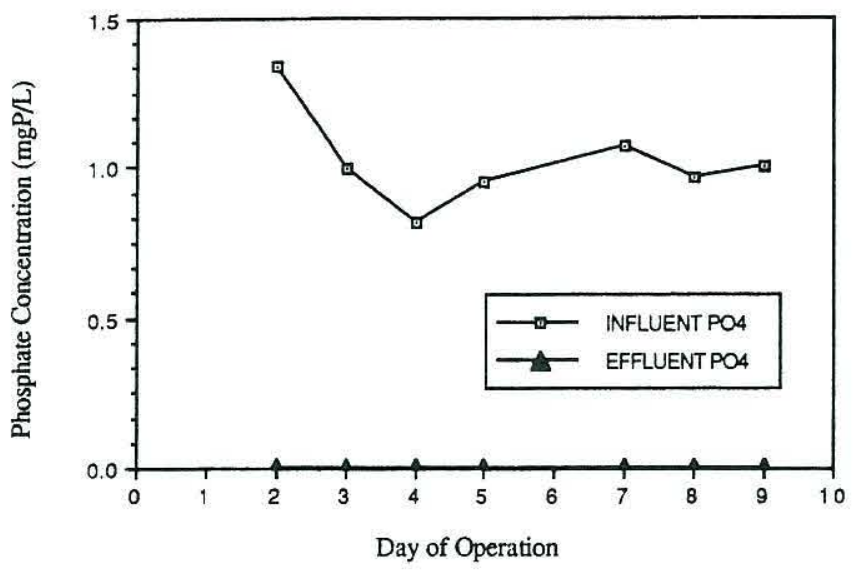

Figure 7-Phosphate removal from sewage effluent using the MAFEB reactor at $20^{\circ} \mathrm{C}$.

observed previously with synthetic nutrient feeds. In terms of methane use, the efficiencies of nitrogen and phosphorus uptake averaged $6.5 \mathrm{mg} \mathrm{N} / \mathrm{g} \mathrm{COD}$ and $0.8 \mathrm{mg} \mathrm{P} / \mathrm{g}$ COD (Table 5), which are similar to those observed with synthetic nutrient mixtures (Table 3).

Lower growth rates were observed during treatment of sewage effluent at 20 and $22^{\circ} \mathrm{C}$ than at $35^{\circ} \mathrm{C}$. These low growth rates translated into lower nutrient uptake rates, both on the basis of resident biomass and on the basis of bed volume (Table 5). However, the removal efficiencies of ammonia and phosphate were not reduced at the lower temperatures because all runs were nutrient limited, not growth rate limited. The low nutrient uptake rates ( $\mathrm{mg} \mathrm{N} / \mathrm{g}$ VS $\cdot \mathrm{d}$ ) observed at the low operating temperatures were probably a result of lower nutrient loading rates during the low temperature experiments (Table 5).

The MAFEB effluent was usually clear during treatment of secondary sewage effluent. Reactor effluent contained 8-30 mg VSS/L, while the suspended solids in the feed varied from 35 to $70 \mathrm{mg}$ VSS/L. The low suspended solids concentrations in the MAFEB effluent were achieved only by settling in the MAFEB clarifier zone ( $10-\mathrm{cm}$ high quiescent zone above the bed), without the use of an external clarifier. The average COD concentration in the MAFEB effluent was about $30 \mathrm{mg}$ COD/ $\mathrm{L}$, while that of the sewage effluent being treated was about 40 $\mathrm{mg} C \mathrm{CD} / \mathrm{L}$. The biodegradable fraction of this organic matter was not measured.

Scale-up considerations. A hypothesized MAFEB system, designed for tertiary treatment of domestic sewage from a population of 10000 , is shown in Figure 8. This system is designed to treat typical secondary sewage effluent containing about 30 $\mathrm{mg} \mathrm{N} / \mathrm{L}$ and $6 \mathrm{mg} \mathrm{P} / \mathrm{L}$, at a flow rate of $4 \times 10^{6} \mathrm{~L} /$ day (Metcalf

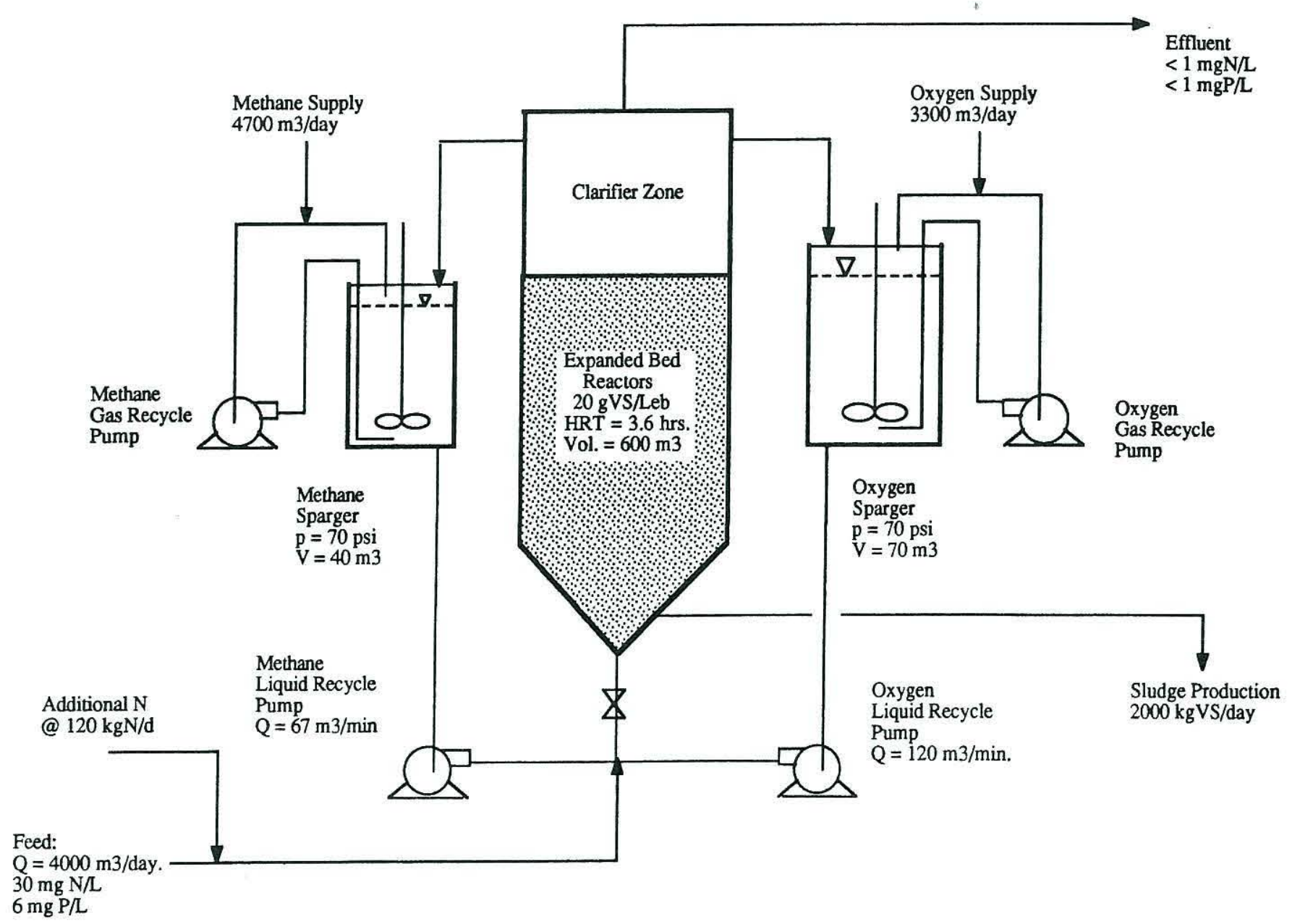

Figure 8-Schematic of MAFEB scale-up unit for tertiary treatment of domestic sewage from 10000 people. 
and Eddy, Inc., 1979). Calculations for this design are based on experimental data obtained from the continuous flow runs with sewage effluent in the laboratory-scale reactors (Table 6 ). The observed yield was taken as $0.15 \mathrm{~g} \mathrm{VS} / \mathrm{g}$ COD, the specific growth rate as $0.17 \mathrm{day}^{-1}$, and the nitrogen content of the solids was assumed to be $12 \%$. In order to accomplish complete phosphorus removal, it is proposed that nitrogen be added to increase the influent $\mathrm{N} / \mathrm{P}$ ratio to $10: 1$. This would require the addition of $120 \mathrm{~kg} \mathrm{~N} /$ day.

Based on the experimental data, a 3.5 hour hydraulic retention time would be required in the bed, resulting in a design fluidized bed volume of $600 \mathrm{~m}^{3}$ with attached solids in the bed at a concentration of $20 \mathrm{~g} \mathrm{VS} / L_{\mathrm{cb}}$. Methane and oxygen consumption would be 3300 and $7500 \mathrm{~m}^{3} /$ day, respectively. It is proposed that methane and oxygen transfer be carried out in spargers or down-flow bubble contactors operated at about 70 psi to increase gas solubilities. Even with the increased solubility afforded by operating at elevated pressures, high liquid recycle rates would be required. These liquid recycle rates would require pumping at about 70 and $120 \mathrm{~m}^{3} /$ minute for the methane and oxygen liquid recycles, respectively. Because of this high flow rate, a large reactor cross-sectional area would be required to avoid unacceptably high upflow velocities in the fluidized bed. For example, an upflow velocity of $25 \mathrm{~cm} /$ minute in the laboratoryscale reactors resulted in 50-100\% bed expansion using support media $0.3-1.0 \mathrm{~mm}$ in diameter. A cross-sectional area of 750 $\mathrm{m}^{2}$ would be required in the large scale system in order to maintain this low upflow velocity. Since the bed volume is $600 \mathrm{~m}^{3}$, design of a practical system will probably require using larger support media so that higher upflow velocities can be tolerated.

The predicted sludge production from this system is $2000 \mathrm{~kg}$ VS/day, based on a nitrogen content of $12 \%$ of the VS. In several of the laboratory-scale experiments, it was suspected that methane was being utilized for the production of carbonaceous storage materials, and the nitrogen content was estimated to be as low as $4 \%$ of the total VS. However, it is presumed that production of this storage material would be minimized in a full-scale system by controlling the methane supply. The estimated sludge production from the methanotrophic process is similar in quantity to that produced by conventional phosphorus removal techniques. For example, treatment of $4000 \mathrm{~m}^{3} /$ day of sewage effluent with lime addition would typically result in 1000-3000 kg dry solids/day (Metcalf and Eddy, Inc., 1979). However, the methanotrophic biomass could be much more useful for

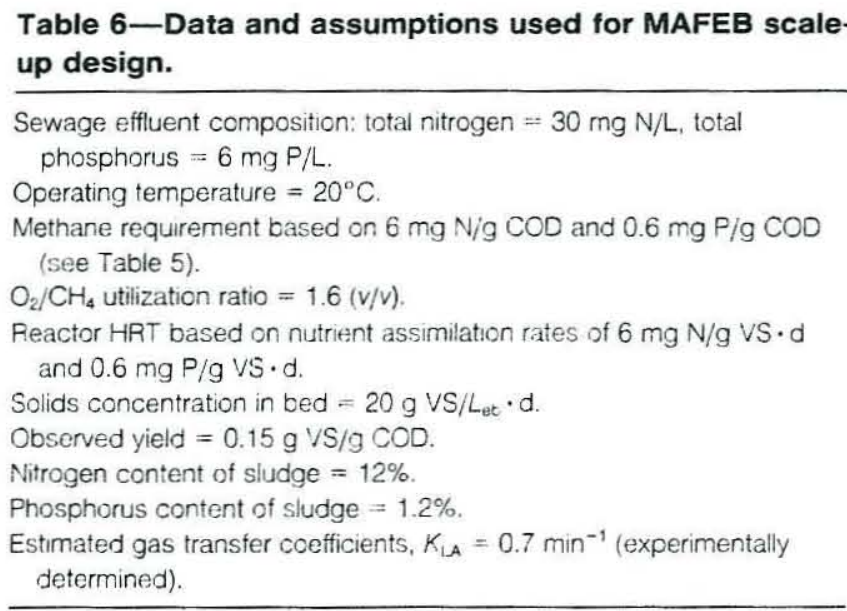

land application and/or an animal feed supplement than sludge from lime precipitation.

The cost of methane to operate the proposed system would be a significant expense. At a cost of $\$ 0.09$ per cubic meter $(\$ 2.50$ per million Btu), the daily cost for natural gas would be about $\$ 0.14$ per cubic meter treated ( $\$ 0.50$ per 1000 gal.). The daily cost of methane for the system in Figure 8 would be about $\$ 400$ / day. However, the cost of methane might be offset by the value of the sludge produced if a market for the methanotrophic solids were developed. For the hypothesized system in Figure 8, sludge value would completely offset the cost of methane if the sludge could be sold for a net price of $\$ 0.20 / \mathrm{kg}(\$ 200 /$ dry ton $)$. Marketability of the methanotrophic sludge will be a key factor in the cost-effectiveness of the MAFEB nutrient removal system.

The system discussed above was designed to provide tertiary treatment following conventional secondary sewage treatment. An alternative approach would be to combine secondary and tertiary treatment into a single process. In the example above, methane was added at a rate of $3.3 \times 10^{6} \mathrm{~g}$ methane/day or 1.3 $\times 10^{7} \mathrm{~g} \mathrm{COD} /$ day. In comparison, typical wastewater containing $500 \mathrm{mg} \mathrm{COD} / \mathrm{L}$ at this flow rate would result in an organic loading rate of about $2 \times 10^{6} \mathrm{~g} \mathrm{COD} /$ day. Thus, the influent COD present in the raw wastewater would constitute only about one-sixth of the total COD consumed in a combined system. The methanotrophic nutrient removal system could therefore be operated with raw sewage with only a minimal additional oxygen requirement relative to that of the tertiary system alone. Combining secondary and tertiary treatment would be expected to reduce the overall cost of the system.

\section{Conclusions}

Nutrient removal with the laboratory-scale MAFEB system was successful, both using synthetic nutrient mixtures and actual secondary sewage effluent. Limiting nutrients in the synthetic nutrient mixtures were assimilated with $99 \%$ or greater removal efficiency. Simultaneous removal of ammonia and phosphate was observed from synthetic nutrient mixtures with a nitrogen to phosphorus ratio of $9: 1$. During treatment of sewage effluent, phosphate was consistently removed to below $0.1 \mathrm{mg} \mathrm{P} / \mathrm{L}$, and the ammonia removal efficiency varied from 94 to $99 \%$. These removal rates were achieved without the addition of any supplements to the sewage effluent.

The MAFEB system was capable of operating with extremely low nutrient concentrations. Continuous flow operation was demonstrated with phosphate concentrations below the detection limits of the ion chromatograph $(<0.1 \mathrm{mg} \mathrm{P} / \mathrm{L})$ and with ammonia concentrations below $0.05 \mathrm{mg} \mathrm{N} / \mathrm{L}$. Operation under these nutrient-starved conditions appears to have resulted in the formation of extracellular storage products, which increased the consumption of methane and increased the volume of the fluidized bed. Aside from these observation, no adverse effects on methanotrophic growth were observed while operating with extremely low nutrient concentrations.

While use of the MAFEB system for tertiary sewage treatment was successful on a laboratory scale, the feasibility of pilot- or full-scale systems remains to be demonstrated. Supplying the required dissolved gases to the fluidized bed may be difficult and require high liquid recycle rates and/or high operating pressures. High liquid recycle rates would result in high pumping costs, and also would create high upflow velocities in the fluidized bed. In order to avoid excess fluidization of the bed, large reactor 
cross-sectional areas and/or larger support particles may be needed.

Additional work with larger-scale MAFEB systems would be required to fully demonstrate the feasibility of the system and to optimize the reactor design and operating conditions. Further consideration should also be given to other types of reactors, such as trickling filters, rotating biological contactors and/or completely mixed systems. For example, a methanotrophic CSTR would provide a simpler design that could overcome some of the limitations of the MAFEB system, by eliminating the need for separate gas-transfer units. The CSTR would be more conventional than the MAFEB, consisting essentially of a covered activated sludge system with increased gas transfer capability. Key issues with a methanotrophic CSTR would include operation with low methane concentrations to avoid explosion hazards, and settleability of the methanotrophic solids. Evaluation of a completely mixed system will be presented in a subsequent paper.

For any methanotrophic tertiary treatment system, the costeffectiveness of the process is limited by the cost of methane and the volume of sludge production. Cost effective application of this system may depend on developing a market for the methanotrophic sludge.

\section{Acknowledgments}

Credits. The authors are grateful for the advice of Dr. Thomas White and Ms. Donna Fennell, and for the technical assistance of Mr. Timothy Nock. Financial support from the Gas Research Institute is gratefully acknowledged.

Authors. Yarrow M. Nelson and Mark S. Wilson are Research Support Specialists and William J. Jewell is a professor in the Department of Agricultural and Biological Engineering in the College of Agricultural and Life Sciences, Cornell University, Ithaca, N.Y. Correspondence should be addressed to Yarrow M. Nelson, Dept. of Agricultural and Biological Engineering, College of Agricultural and Life Sciences, Riley Robb Hall, Ithaca, NY 14853.

Submitted for publication December 20, 1991; revised manuscript submitted April 4, 1992; accepted for publication April 9, 1992. The deadline for discussions of this paper is January 15, 1993. Discussions should be submitted to the Executive Editor. The authors will be invited to prepare a single Closure for all discussions received before that date.

\section{References}

Chaudhry, G. R., and Chapalamadugu, S. (1991) Biodegradation of Halogenated Organic Compounds. Mficrohio. Rev., 55, 59.

Clarkson. W. W. (1986) Fermentation of Particulate Organic Matter to Methane in a Thermophilic Anaerobic Attached Film Expanded Bed Reactor. Ph.D. thesis, Cornell Univ.. Ithaca, N. Y.

Fennell, D. E., and Jewell. W. J. ( 1992) Methanotrophic Attached Film Reactors: System Development and Biofilm Characteristics. In preparation.

Fogel. M. M., et al. (1986) Biodegradation of Chlorinated Ethenes by a Methane-utilizing Mixed Culture. Appl. Environ. Microbiol., 51, 720 .

Hamer, G., et al. (1967) Methane as a Carbon Substrate for the Production of Microbial Cells. Biotechnol. Bioeng.. 9, 499.

Harrison, D. E. F., et al. (1972) Yield and Productivity in Single-cell Protein Production from Methane and Methanol. Proc. IV IFS. Ferment. Technol. Todav. 491.

Jewell, W. J., et al. (1989) Methanotrophs and Methanogens for Pollution Control: PCE and TCE Removal from Groundwater and Macro Nutrient Removals from Wastewater. Annual research report to the Gas Research Institute and Radian Corporation, Chicago, Ill.

Jewell, W. J., et al. (1990) Methanotrophs and Methanogens for Pollution Control: PCE and TCE Removal from Groundwater and Macro Nutrient Removals from Wastewater. Annual research report to the Gas Research Institute and Radian Corporation, Chicago, Ill.

Jewell, W. J., et al. (1991) Methanotrophs and Methanogens for Pollution Control: PCE and TCE Removal from Groundwater and Macro Nutrient Removals from Wastewater. Annual research report to the Gas Research Institute and Radian Corporation, Chicago, Ill.

Leak, D. J., and Dalton, H. (1986) Growth yields of methanotrophs. Appl. Microbiol. Biotechnol., 23, 470.

Metcalf and Eddy, Inc. (1979) Wastewater Engineering: Treatment/ Disposal/Reuse., 2nd Ed., McGraw-Hill, New York, N. Y.

Rutzke, M. (1991) Dep. of Fruit and Vegetable Sci., Cornell Univ., Ithaca, N. Y. Personal Communication.

Sheehan, B. T., and Johnson, M. J. (1971) Production of Bacterial Cells from Methane. Appl. Microbiol., 21, 511.

Standard Methods for the Examination of Water and Wastewater (1989). 17th Ed., Am. Public Health Assoc., Washington. D. C.

Van Note, R. H., et al. (1975) A Guide to the Selection of Cost-effective Wastewater Treatment Systems. U. S. EPA. Rep. EPA-430/9-75002, Washington, D. C.

Vary, P. S., and Johnson, M. J. (1967) Cell Yields of Bacteria Grown on Methane. Appl. Microbiol., 15, 1473.

Wilson, J. T., and Wilson, B. H. (1985) Biotransformation of Trichloroethylene in Soil. Appl. Environ. Microbiol., 49, 242. 